\title{
Foaming Agents for Powder Metallurgy Production of Aluminum Foam
}

\author{
Takuya Koizumi ${ }^{1, *}$, Kota Kido ${ }^{1}$, Kazuhiko Kita ${ }^{1}$, Koichi Mikado ${ }^{2}$, \\ Svyatoslav Gnyloskurenko ${ }^{3}$ and Takashi Nakamura ${ }^{3}$ \\ ${ }^{1}$ Machinery and Engineering Group, YKK Corporation, Kurobe 938-8601, Japan \\ ${ }^{2}$ Fastening Products Group, YKK Corporation, Kurobe 938-8601, Japan \\ ${ }^{3}$ Institute of Multidisciplinary Research for Advanced Materials, Tohoku University, Sendai 980-8577, Japan
}

\begin{abstract}
Metallic foams are commonly produced using hydride foaming agents. Carbonates are safer to handle than hydrides; however, their use in the powder metallurgy (PM) route to obtaining a fine and homogenous cell structure has not been evaluated. In this study, carbonates and hydroxides were investigated as foaming agents for the production of $\mathrm{Al}-\mathrm{Si}-\mathrm{Cu}$ alloy foams by the PM route. The thermal decomposition behavior of the foaming agents was evaluated in conjunction with the cell structure of the aluminum foams produced. From the results, it was clarified that a foaming agent that began decomposing after the matrix melted is required to obtain a fine and homogenous cell structure. The $\mathrm{TiH}_{2}$ foam formed under similar conditions was obviously different and had a coarse and rounded cell structure. $\mathrm{MgCO} 3$ and CaMg$\left(\mathrm{CO}_{3}\right)_{2}$ were selected as suitable foaming agents for the $\mathrm{Al}-\mathrm{Si}-\mathrm{Cu}$ alloy. Once expanded, the $\mathrm{CaMg}\left(\mathrm{CO}_{3}\right)_{2}$ foam had a specific gravity of 1.19 and a homogeneous, fine and spherical cell structure. [doi:10.2320/matertrans.M2010401]
\end{abstract}

(Received November 29, 2010; Accepted January 12, 2011; Published April 1, 2011)

Keywords: foaming agent, metallic foam, carbonate, titanium hydride, powder metallurgy route, magnesium carbonate, dolomite

\section{Introduction}

Metallic foams have unique properties, such as low density, good energy absorbing capability and low thermal conductivity. Recent research has focused on these foams, and many processes have been proposed for their manufacture. Among these processes, the use of titanium hydride $\left(\mathrm{TiH}_{2}\right)$ as a foaming agent is popular in melt processing and powder metallurgy (PM). Alporas foams are produced by a typical melt processing route, ${ }^{1)}$ in which foams are melted with calcium as a viscosity-enhancing additive and a $\mathrm{TiH}_{2}$ foaming agent. The Fraunhofer method is a typical PM route $^{2)}$ that involves the hot extrusion of an aluminum matrix powder and $\mathrm{a} \mathrm{TiH}_{2}$ precursor, which is then heated in a closed die to foam for near-net shaping. Compared with the Alporas method, the Fraunhofer method is more expensive and provides a better control of the cell structure and near-net shaping.

$\mathrm{TiH}_{2}$ is a popular foaming agent because of its decomposition temperature, which is close to the melting temperature of aluminum alloys. However, $\mathrm{TiH}_{2}$ is expensive and dangerous to handle. Therefore, a cheaper and safer foaming agent is required. Calcium carbonate $\left(\mathrm{CaCO}_{3}\right)$, which is a cheap and very stable alternative to $\mathrm{TiH}_{2}$, has been used as the foaming agent in the melt processing route. ${ }^{3)}$ The use of calcium carbonate in the PM route has not been thoroughly investigated.

In the PM route, the precursor is heated in a metal die. Low temperatures are preferred for this route because of the thermal resistivity of the die material and to reduce the energy requirements of the process. The aluminum alloy Al$\mathrm{Si}-\mathrm{Cu}$ has a lower melting temperature than other alloys because the $\mathrm{Al}-\mathrm{Si}$ and $\mathrm{Al}-\mathrm{Si}-\mathrm{Cu}$ mixtures are eutectic.

In the present study, carbonate and hydroxide were investigated as foaming agents for the $\mathrm{Al}-\mathrm{Si}-\mathrm{Cu}$ alloy by the PM route.

*Corresponding author, E-mail: t-koizumi@ykk.co.jp
Table 1 Foaming agents.

\begin{tabular}{|c|c|c|c|c|}
\hline \multicolumn{2}{|c|}{ Foaming agent } & \multirow{2}{*}{$\begin{array}{c}\begin{array}{c}\text { Average } \\
\text { particle }\end{array} \\
\text { size, } d / \mu \mathrm{m}\end{array}$} & \multirow{2}{*}{$\begin{array}{c}\text { Gas } \\
\mathrm{H}_{2}\end{array}$} & \multirow[b]{2}{*}{$\mathrm{TiH}_{2}=\mathrm{Ti}+\mathrm{H}_{2}$} \\
\hline $\begin{array}{l}\text { Titanium } \\
\text { hydride }\end{array}$ & $\mathrm{TiH}_{2}$ & & & \\
\hline $\begin{array}{l}\text { Magnesium } \\
\text { hydroxide }\end{array}$ & $\mathrm{Mg}(\mathrm{OH})_{2}$ & 7.4 & $\mathrm{H}_{2} \mathrm{O}$ & $\mathrm{Mg}(\mathrm{OH})_{2}=\mathrm{MgO}+\mathrm{H}_{2} \mathrm{O}$ \\
\hline $\begin{array}{l}\text { Magnesium } \\
\text { carbonate } \\
\text { hydroxide }\end{array}$ & $\begin{array}{l}4 \mathrm{MgCO}_{3} \\
\cdot \mathrm{Mg}(\mathrm{OH})_{2} \\
\cdot 5 \mathrm{H}_{2} \mathrm{O}\end{array}$ & 11 & $\begin{array}{l}\mathrm{H}_{2} \mathrm{O} \\
\mathrm{CO}_{2}\end{array}$ & $\begin{array}{l}4 \mathrm{MgCO}_{3}-\mathrm{Mg}(\mathrm{OH})_{2}-5 \mathrm{H}_{2} \mathrm{O} \\
=4 \mathrm{MgCO}_{3}+\mathrm{MgO}+6 \mathrm{H}_{2} \mathrm{O} \\
4 \mathrm{MgCO}_{3}=4 \mathrm{MgO}+4 \mathrm{CO}_{2}\end{array}$ \\
\hline $\begin{array}{l}\text { Magnesium } \\
\text { carbonate }\end{array}$ & $\mathrm{MgCO}_{3}$ & 11 & $\mathrm{CO}_{2}$ & $\mathrm{MgCO}_{3}=\mathrm{MgO}+\mathrm{CO}_{2}$ \\
\hline Dolomite & $\mathrm{CaMg}\left(\mathrm{CO}_{3}\right)_{2}$ & - & $\begin{array}{l}\mathrm{CO}_{2} \\
\mathrm{CO}_{2}\end{array}$ & $\begin{array}{l}\mathrm{CaMg}\left(\mathrm{CO}_{3}\right)_{2} \\
\quad=\mathrm{CaCO}_{3}+\mathrm{MgO}+\mathrm{CO}_{2} \\
\mathrm{CaCO}_{3}=\mathrm{CaO}+\mathrm{CO}_{2}\end{array}$ \\
\hline $\begin{array}{l}\text { Calcium } \\
\text { carbonate }\end{array}$ & $\mathrm{CaCO}_{3}$ & 13.5 & $\mathrm{CO}_{2}$ & $\mathrm{CaCO}_{3}=\mathrm{CaO}+\mathrm{CO}_{2}$ \\
\hline
\end{tabular}

\section{Experimental}

Air-atomized $\mathrm{AlSiCu}$ powder containing mass fractions of $\mathrm{Si}(10.8 \%)$ and $\mathrm{Cu}(2.4 \%)$, was used to make the precursor. The powder was sieved through a $150 \mu \mathrm{m}$ mesh before use.

$\mathrm{TiH}_{2}$, magnesium hydroxide $\left(\mathrm{MgOH}_{2}\right)$, magnesium carbonate hydroxide $\left(4 \mathrm{MgCO}_{3} \cdot \mathrm{Mg}(\mathrm{OH})_{2} \cdot 5 \mathrm{H}_{2} \mathrm{O}\right)$, magnesium carbonate $\left(\mathrm{MgCO}_{3}\right)$, dolomite $\left(\mathrm{CaMg}\left(\mathrm{CO}_{3}\right)_{2}\right)$, and calcium carbonate $\left(\mathrm{CaCO}_{3}\right)$ were investigated as foaming agents. Their particle sizes and chemical reactions are given in Table 1. In their reactions, $\mathrm{TiH}_{2}$ releases hydrogen $\left(\mathrm{H}_{2}\right)$, $\mathrm{MgOH}_{2}$ releases water vapor $\left(\mathrm{H}_{2} \mathrm{O}\right)$, and $4 \mathrm{MgCO}_{3}$. $\mathrm{Mg}(\mathrm{OH})_{2} \cdot 5 \mathrm{H}_{2} \mathrm{O}$ releases $\mathrm{H}_{2} \mathrm{O}$ and carbon dioxide $\left(\mathrm{CO}_{2}\right)$, while $\mathrm{MgCO}_{3}, \mathrm{CaMg}\left(\mathrm{CO}_{3}\right)_{2}$ and $\mathrm{CaCO}_{3}$ release $\mathrm{CO}_{2}$.

$\mathrm{CaMg}\left(\mathrm{CO}_{3}\right)_{2}$ is a mineral made of $\mathrm{CaCO}_{3}$ and $\mathrm{MgCO}_{3}$, and its composition and purity depend on the area of the mine 
Table 2 Dolomites.

\begin{tabular}{cccc}
\hline Supplier & Size & $\begin{array}{c}\text { Composition } \\
\text { (catalog) }\end{array}$ & $\begin{array}{c}\text { Composition } \\
\text { (measured, mass\%) }\end{array}$ \\
\hline $\begin{array}{c}\text { Murakashi } \\
\text { Lime Industry }\end{array}$ & $\begin{array}{c}3.5 \mu \mathrm{m} \\
\text { (average) }\end{array}$ & $\begin{array}{c}\mathrm{Ca}>20 \%, \\
\mathrm{Mg}>10 \%\end{array}$ & $\begin{array}{c}\mathrm{CaO}: 70.8, \\
\mathrm{MgO}: 28.1\end{array}$ \\
\hline $\begin{array}{c}\text { Yoshizawa } \\
\text { Lime Industry }\end{array}$ & Coarse & - & $\mathrm{CaO}: 73.7$, \\
\hline \multirow{2}{*}{ JFE Mineral } & $<2.36 \mathrm{~mm}$ & $\mathrm{CaO}=34.5 \%$, & $\mathrm{CaO}: 73.8$, \\
& & $\mathrm{MgO}=18.3 \%$ & $\mathrm{MgO}: 25.0$ \\
\hline
\end{tabular}

it was obtained from. The $\mathrm{CaMg}\left(\mathrm{CO}_{3}\right)_{2}$ samples used in this study were obtained from Murakashi Lime Industry Co., Ltd. (ML), Yoshizawa Lime Industry Co., Ltd. (YL) and JFE Mineral Co., Ltd. (JFE). The data for these samples are shown in Table 2.

The thermogravimetric analysis and differential thermal analysis (TG-DTA) systems obtained from Seiko Instruments Inc. were used to examine the melting of $\mathrm{AlSiCu}$ and the thermal decomposition of foaming agents in argon flow. The samples were heated in alumina pans with a heating rate of $10 \mathrm{~K} / \mathrm{min}$.

Precursors were formed by hot extrusion at $623 \mathrm{~K}$ using a mixture of the $\mathrm{AlSiCu}$ powder and foaming agent. The extrusion ratio was 18 , and the cross section of each precursor was $5 \mathrm{~mm}$ high $\times 15 \mathrm{~mm}$ wide. The precursors were cut to $30 \mathrm{~mm}$ lengths measured with a Type $\mathrm{K}$ thermocouple, and they were heated to specific temperatures in a furnace. The formed aluminum foams were cooled in air when expansion started at $843 \mathrm{~K}$. The specific gravity of each foam was measured using the Archimedes principle, and the cell structure of the foams was observed by optical microscopy.

\section{Results and Discussion}

\subsection{Decomposition of foaming agent}

The TG-DTA of AlSiCu (Fig. 1) showed that it started melting at $793 \mathrm{~K}$, and melting was complete at $853 \mathrm{~K}$. Consequently, it is necessary for the foaming agent to decompose between 793 and $853 \mathrm{~K}$ when using $\mathrm{AlSiCu}$ as the matrix. The liquidus temperature of $\mathrm{AlSiCu}$ was $80 \mathrm{~K}$ lower than that of pure aluminum.

The TG-DTA curves of $\mathrm{TiH}_{2}, \mathrm{Mg}(\mathrm{OH})_{2}$, and $4 \mathrm{MgCO}_{3}$. $\mathrm{Mg}(\mathrm{OH})_{2} \cdot 5 \mathrm{H}_{2} \mathrm{O}$ are shown in Fig. 2, and those of $\mathrm{MgCO}_{3}$ and $\mathrm{CaCO}_{3}$ are shown in Fig. 3. Starting at $703 \mathrm{~K}$, the mass of $\mathrm{TiH}_{2}$ decreased with the release of $\mathrm{H}_{2}$, and this release was complete at $933 \mathrm{~K}$. The decomposition temperature of $\mathrm{TiH}_{2}$ is within the melting temperature range of $\mathrm{AlSiCu}$, which indicates that $\mathrm{TiH}_{2}$ is a suitable foaming agent of $\mathrm{AlSiCu}$. In contrast, neither $\mathrm{Mg}(\mathrm{OH})_{2}$ nor $4 \mathrm{MgCO}_{3} \cdot \mathrm{Mg}(\mathrm{OH})_{2} \cdot 5 \mathrm{H}_{2} \mathrm{O}$ is an appropriate foaming agent of $\mathrm{AlSiCu}$. Most $\mathrm{Mg}(\mathrm{OH})_{2}$ decomposes between 633 and $753 \mathrm{~K}$ while releasing $\mathrm{H}_{2} \mathrm{O}$, which occurs before $\mathrm{AlSiCu}$ begins melting. During the decomposition of $4 \mathrm{MgCO}_{3} \cdot \mathrm{Mg}(\mathrm{OH})_{2} \cdot 5 \mathrm{H}_{2} \mathrm{O}, \mathrm{H}_{2} \mathrm{O}$ is released from ambient temperature to $613 \mathrm{~K}$, and then $\mathrm{CO}_{2}$ is released by the decomposition of $\mathrm{MgCO}_{3}$ from 613 to $833 \mathrm{~K}$. Before $\mathrm{AlSiCu}$ begins to melt, $\mathrm{H}_{2} \mathrm{O}$ and most of the $\mathrm{CO}_{2}$ are released. $\mathrm{MgCO}_{3}$ decomposes from 793 to $993 \mathrm{~K}$, which is close to the melting temperature range of $\mathrm{AlSiCu}$. Therefore,

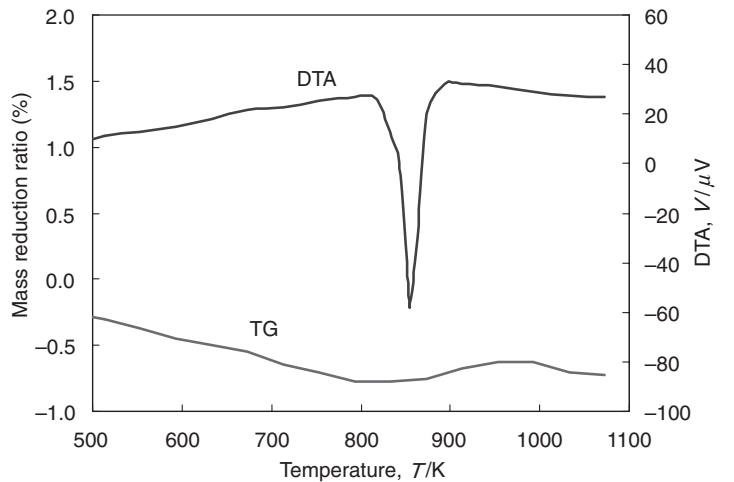

Fig. 1 DTA and TG curves of Al-10.8Si-2.4Cu (mass\%).

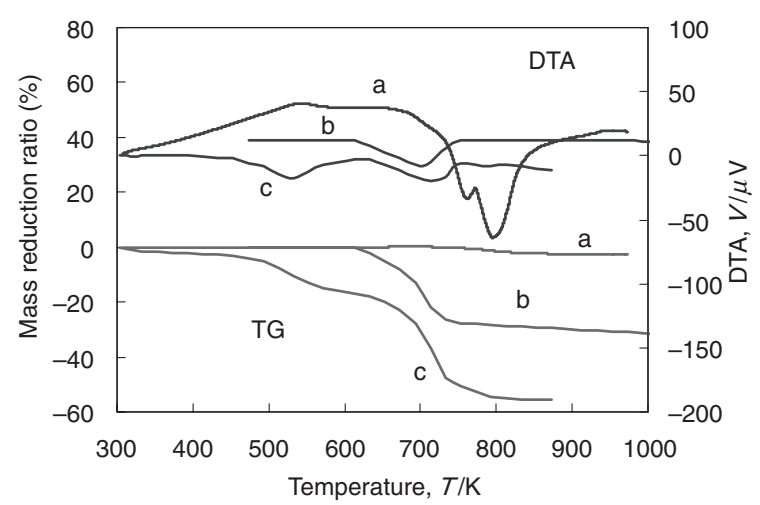

Fig. 2 DTA and TG curves of foaming agents: (a) $\mathrm{TiH}_{2}$, (b) $\mathrm{Mg}(\mathrm{OH})_{2}$, and (c) $4 \mathrm{MgCO}_{3} \cdot \mathrm{Mg}(\mathrm{OH})_{2} \cdot 5 \mathrm{H}_{2} \mathrm{O}$.

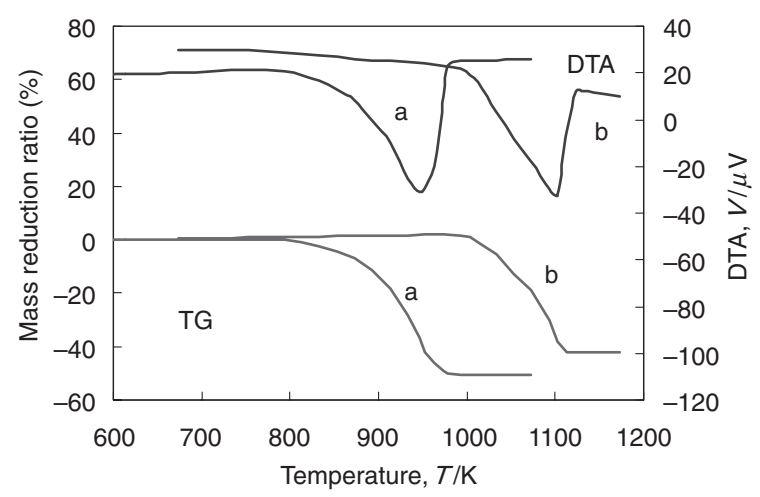

Fig. 3 DTA and TG curves of foaming agents: (a) $\mathrm{MgCO}_{3}$ and (b) $\mathrm{CaCO}_{3}$.

$\mathrm{MgCO}_{3}$ is a suitable foaming agent of $\mathrm{AlSiCu}$. However, $\mathrm{CaCO}_{3}$ decomposes over $993 \mathrm{~K}$, which indicates that it is not an appropriate foaming agent.

\subsection{Decomposition of $\mathrm{CaMg}\left(\mathrm{CO}_{3}\right)_{2}$}

In the SEM images of the $\mathrm{CaMg}\left(\mathrm{CO}_{3}\right)_{2}$ samples (Fig. 4), the ML-CaMg $\left(\mathrm{CO}_{3}\right)_{2}$ sample showed a homogenous particle distribution. However, the YL- and JFE-CaMg $\left(\mathrm{CO}_{3}\right)_{2}$ samples showed a heterogeneous particle distribution with coarse particles $>0.5 \mathrm{~mm}$ in diameter.

In the TG-DTA curves of the $\mathrm{CaMg}\left(\mathrm{CO}_{3}\right)_{2}$ samples (Fig. 5), two stages of decomposition were observed for YL$\mathrm{CaMg}\left(\mathrm{CO}_{3}\right)_{2}$. The first stage began at $713 \mathrm{~K}$ and the second stage at $1013 \mathrm{~K}$. The $\mathrm{YL}-\mathrm{CaMg}\left(\mathrm{CO}_{3}\right)_{2}$ sample was slightly 
(a)

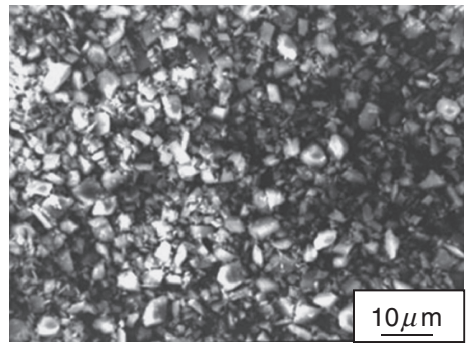

(b)

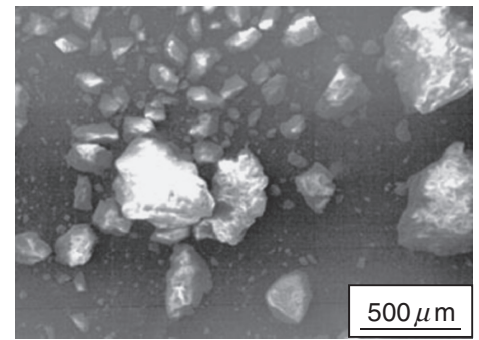

(c)

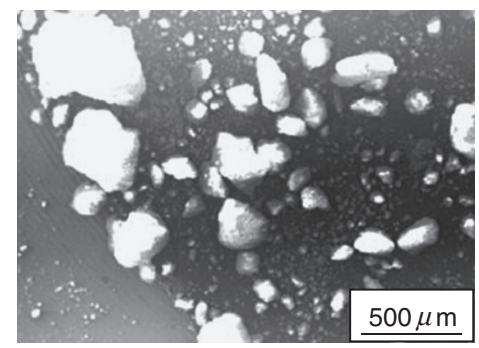

Fig. 4 SEM images of dolomite: (a) Murakashi Lime Industry, (b) Yoshizawa Lime Industry, and (c) JFE Mineral.

wet, and we can assume that the first decomposition stage was the release of $\mathrm{H}_{2} \mathrm{O}$ or the decomposition of $\mathrm{MgCO}_{3}$. For ML- and JFE-CaMg $\left(\mathrm{CO}_{3}\right)_{2}$, the first and second stages began at $773 \mathrm{~K}$ and $1013 \mathrm{~K}$, respectively. The two stages of decomposition for $\mathrm{CaMg}\left(\mathrm{CO}_{3}\right)_{2}$ are shown in Table 1. It has been reported that the number of decomposition stages changes with the type of atmosphere. ${ }^{4)}$ For example, in argon, the decomposition could occur in a single continuous stage.

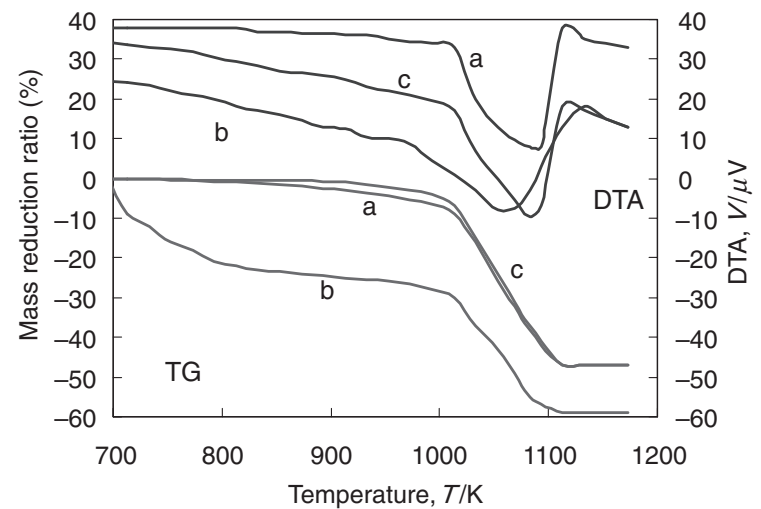

Fig. 5 DTA and TG curves of dolomite: (a) Murakashi Lime Industry, (b) Yoshizawa Lime Industry, and (c) JFE Mineral.

ML-CaMg $\left(\mathrm{CO}_{3}\right)_{2}$ was selected because its particles were fine and homogenous, and its decomposition temperature was close to the melting temperature of AlSiCu.

\subsection{Evaluation of foaming ability}

Precursors were formed with four foaming agents. These were $\mathrm{MgCO}_{3}$ and $\mathrm{CaMg}\left(\mathrm{CO}_{3}\right)_{2}$, which were selected because of their suitability for AlSiCu, and $4 \mathrm{MgCO}_{3} \cdot \mathrm{Mg}(\mathrm{OH})_{2} \cdot 5 \mathrm{H}_{2} \mathrm{O}$ and $\mathrm{TiH}_{2}$, which were selected for comparison.

The distribution of the foaming agent in the precursor is expected to affect the foam cell structure; therefore, it is important for industrial fabrication. Figure 6 shows the SEM images of the foaming agents, and Fig. 7 shows the crosssectional views of the precursors. The $\mathrm{TiH}_{2}$ and $4 \mathrm{MgCO}_{3}$. $\mathrm{Mg}(\mathrm{OH})_{2} \cdot 5 \mathrm{H}_{2} \mathrm{O}$ particles were coarse and agglomerated, while the $\mathrm{MgCO}_{3}$ and $\mathrm{CaMg}\left(\mathrm{CO}_{3}\right)_{2}$ particles were fine and dispersed. $\mathrm{TiH}_{2}$ and $4 \mathrm{MgCO}_{3} \cdot \mathrm{Mg}(\mathrm{OH})_{2} \cdot 5 \mathrm{H}_{2} \mathrm{O}$ were heterogeneously dispersed in the precursor, while $\mathrm{MgCO}_{3}$ and $\mathrm{CaMg}\left(\mathrm{CO}_{3}\right)_{2}$ were homogeneously dispersed.

Figure 8 shows the aluminum foams produced with the four different precursors. After the cooling of the aluminum foams, their specific gravities were measured to range from (a)

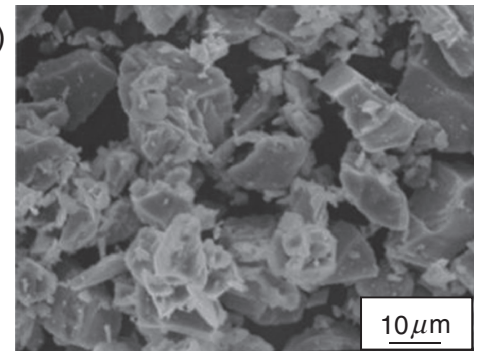

(c)

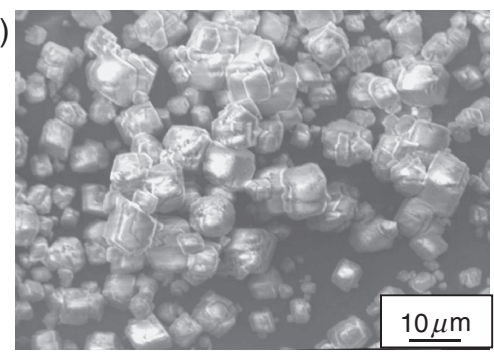

(b)

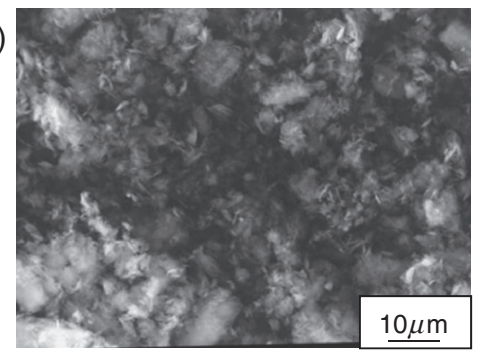

(d)

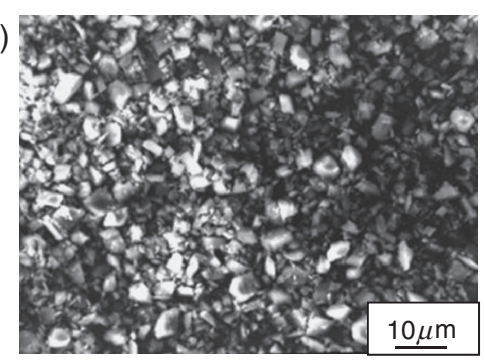

Fig. 6 SEM images of foaming agents: (a) $\mathrm{TiH}_{2}$, (b) $4 \mathrm{MgCO}_{3} \cdot \mathrm{Mg}(\mathrm{OH})_{2} \cdot 5 \mathrm{H}_{2} \mathrm{O}$, (c) $\mathrm{MgCO}_{3}$, and (d) $\mathrm{CaMg}\left(\mathrm{CO}_{3}\right)_{2}$. 
(a)

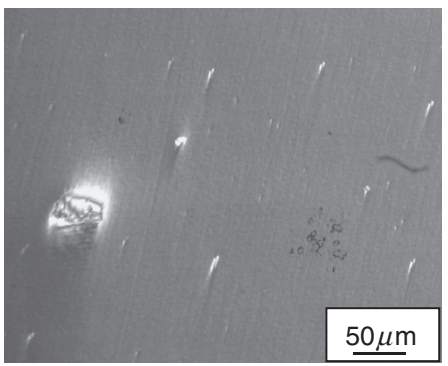

(c)

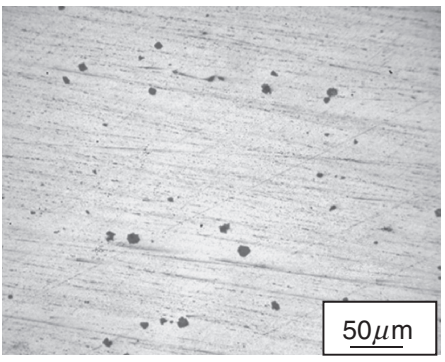

(b)

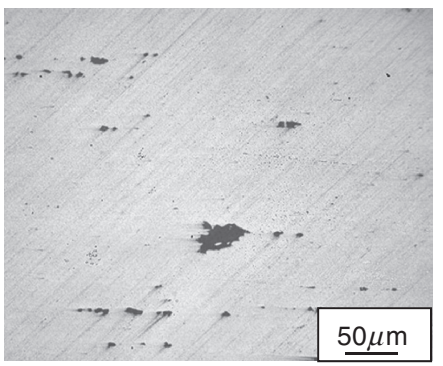

(d)

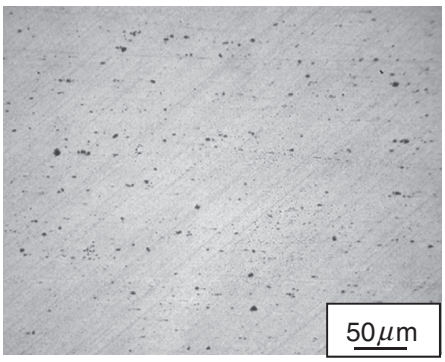

Fig. 7 Dispersion of foaming agent in precursor: (a) $\mathrm{TiH}_{2}$, (b) $4 \mathrm{MgCO}_{3} \cdot \mathrm{Mg}(\mathrm{OH})_{2} \cdot 5 \mathrm{H}_{2} \mathrm{O}$, (c) $\mathrm{MgCO}_{3}$, and (d) $\mathrm{CaMg}\left(\mathrm{CO}_{3}\right)_{2}$.

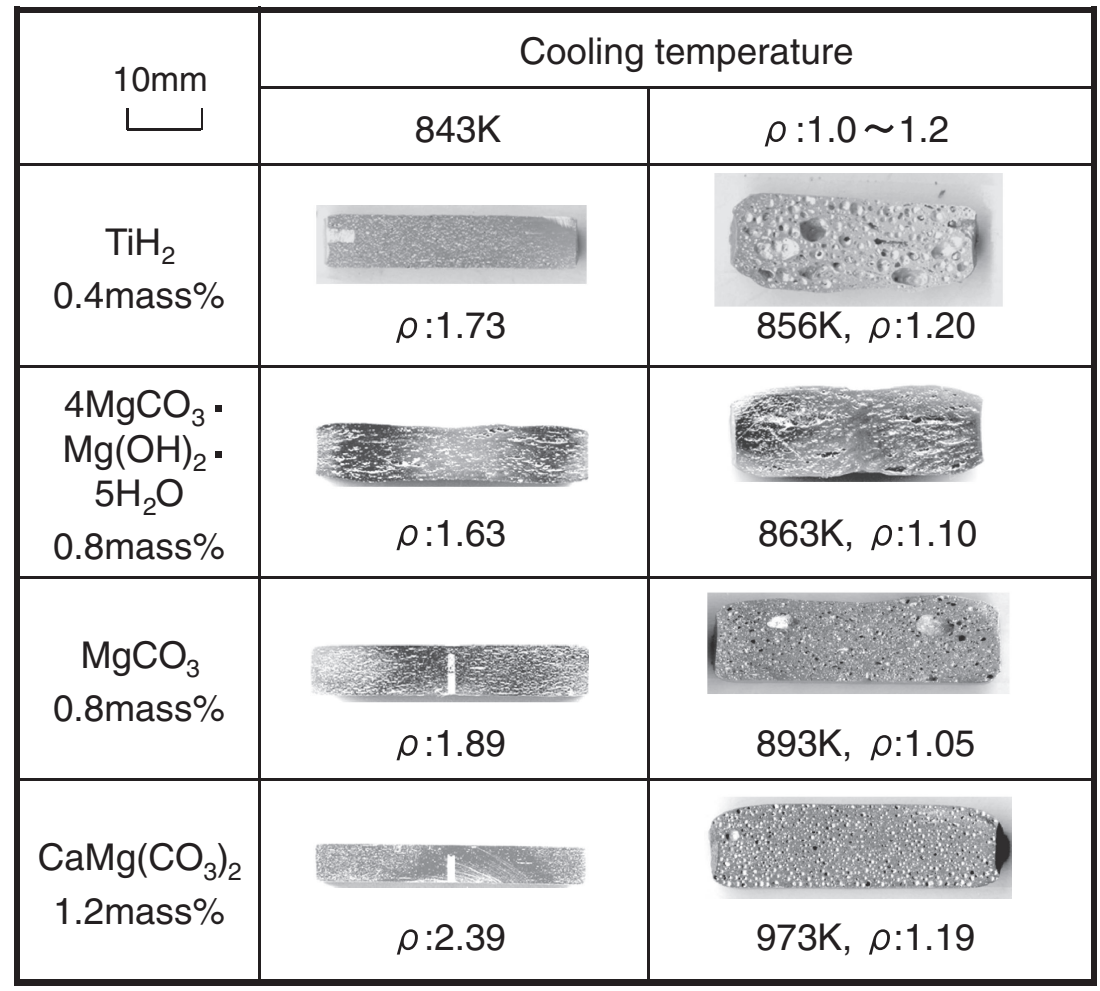

Fig. 8 Effect of foaming agent on cell structure.

1.0 to 1.2 . The $\mathrm{TiH}_{2}$ foam had a fine cell structure at $843 \mathrm{~K}$ when expansion began, and its cell structure became coarse and rounded at $856 \mathrm{~K}$. The $4 \mathrm{MgCO}_{3} \cdot \mathrm{Mg}(\mathrm{OH})_{2} \cdot 5 \mathrm{H}_{2} \mathrm{O}$ foam expanded to have a specific gravity of $<1.2$ at $863 \mathrm{~K}$, but its cell structure was broken along the extrusion direction. Both $\mathrm{MgCO}_{3}$ and $\mathrm{CaMg}\left(\mathrm{CO}_{3}\right)_{2}$ showed a homogenous cell structure, but the homogeneity of $\mathrm{CaMg}\left(\mathrm{CO}_{3}\right)_{2}$ was better. $\mathrm{MgCO}_{3}$ expanded to a specific gravity of $<1.2$ at a lower temperature than $\mathrm{CaMg}\left(\mathrm{CO}_{3}\right)_{2}$. However, the cell structure of $\mathrm{MgCO}_{3}$ was coarser than that of $\mathrm{CaMg}\left(\mathrm{CO}_{3}\right)_{2}$.

\subsection{Effect of foaming agent on cell structure}

The different cell structures obtained from the foaming agents (Fig. 8) are determined by various factors, such as the type of gas released and the decomposition temperature. Figure 9 shows the magnified images of the cell structures after the samples were cooled once expansion began at $843 \mathrm{~K}$. At this temperature, the $\mathrm{TiH}_{2}$ and $4 \mathrm{MgCO}_{3} \cdot \mathrm{Mg}(\mathrm{OH})_{2}$. $5 \mathrm{H}_{2} \mathrm{O}$ foams had broken cell structures, the $\mathrm{MgCO}_{3}$ foam appeared flat, and the $\mathrm{CaMg}\left(\mathrm{CO}_{3}\right)_{2}$ foam had a spherical cell structure. 
(a)

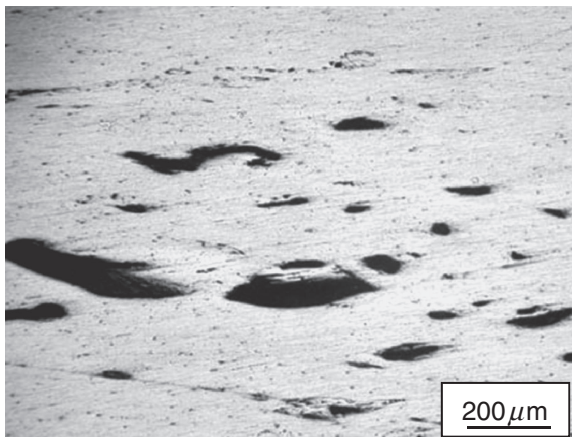

(c)

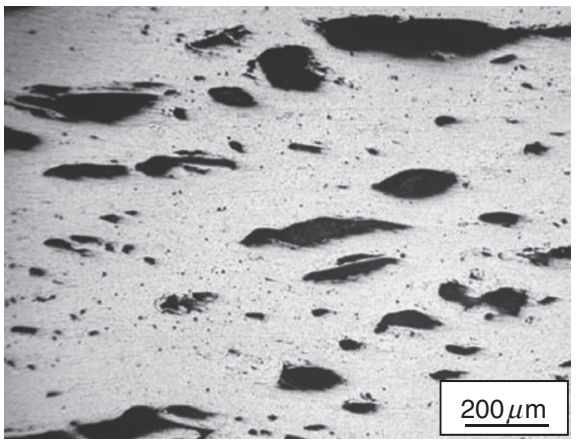

(b)

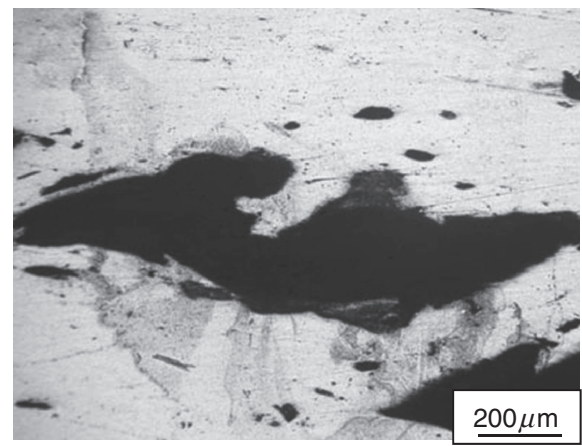

(d)

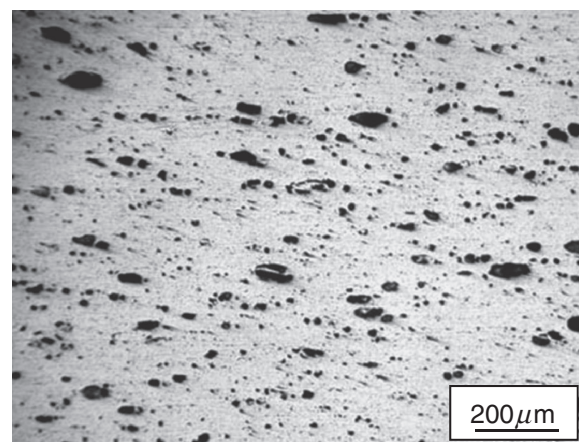

Fig. 9 Microstructures of various foams: (a) $\mathrm{TiH}_{2}$, (b) $4 \mathrm{MgCO}_{3} \cdot \mathrm{Mg}(\mathrm{OH})_{2} \cdot 5 \mathrm{H}_{2} \mathrm{O}$, (c) $\mathrm{MgCO}_{3}$, and (d) $\mathrm{CaMg}\left(\mathrm{CO}_{3}\right)_{2}$.

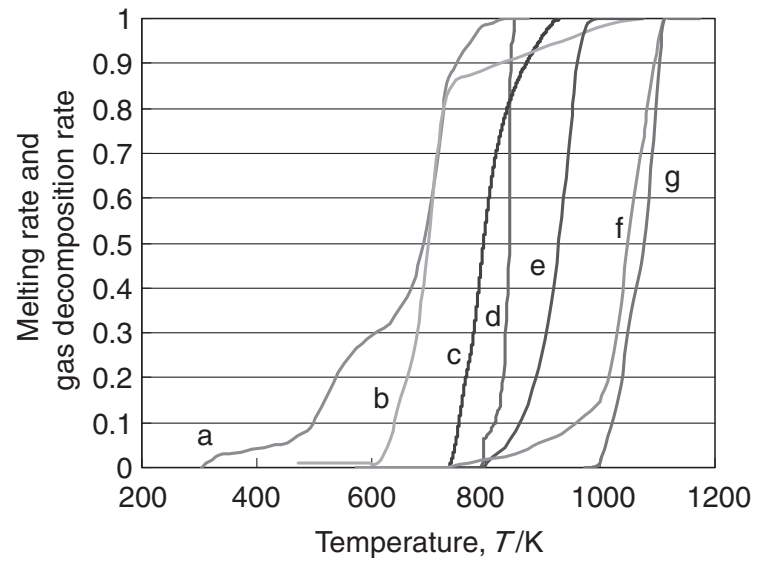

Fig. 10 Melting rates of $\mathrm{AlSiCu}$ and gas decomposition rates of various agents: (a) $4 \mathrm{MgCO}_{3} \cdot \mathrm{Mg}(\mathrm{OH})_{2} \cdot 5 \mathrm{H}_{2} \mathrm{O}$, (b) $\mathrm{Mg}(\mathrm{OH})_{2}$, (c) $\mathrm{TiH}_{2}$. Melting rates of (d) $\mathrm{AlSiCu}$, (e) $\mathrm{MgCO}_{3}$, (f) $\mathrm{CaMg}\left(\mathrm{CO}_{3}\right)_{2}$, and (g) $\mathrm{CaCO}_{3}$.

Figure 10 shows the melting rate of $\mathrm{AlSiCu}^{5)}$ and the decomposition rate of the foaming agent. The decomposition rate was calculated from the mass reduction observed by TG-DTA. The decomposition of both $\mathrm{TiH}_{2}$ and $4 \mathrm{MgCO}_{3}$. $\mathrm{Mg}(\mathrm{OH})_{2} \cdot 5 \mathrm{H}_{2} \mathrm{O}$ began at a low temperature. These foaming agents have released over half of their decomposition gas before $\mathrm{AlSiCu}$ begins to melt. The released gas breaks the extruded aluminum powder boundary because the solid phase has a higher strength than the solid-liquid phase, and broken cells combine and grow in the extrusion direction. At a high temperature, the $\mathrm{TiH}_{2}$ foam forms a coarse and rounded cell structure because the cell structures expanded by $\mathrm{H}_{2}$ are easily combined and deformed to reduce the surface energy of the cell wall.
Table 3 Gas volume and radius at $843 \mathrm{~K}$.

\begin{tabular}{cccccc}
\hline $\begin{array}{c}\text { Foaming } \\
\text { agent }\end{array}$ & $\begin{array}{c}\text { Average } \\
\text { particle } \\
\text { size, } \\
d / \mu \mathrm{m}\end{array}$ & $\begin{array}{c}\text { Gas } \\
\text { mol } \\
\text { per }\end{array}$ & $\begin{array}{c}\text { Decomposition } \\
\text { rate } \\
\text { at } 843 \mathrm{~K}\end{array}$ & $\begin{array}{c}\text { Gas } \\
\text { volume } \\
\text { at } 843 \mathrm{~K}, \\
v / \mathrm{m}^{3}\end{array}$ & $\begin{array}{c}\text { Gas } \\
\text { radius } \\
\text { at } 843 \mathrm{~K}, \\
r / \mu \mathrm{m}\end{array}$ \\
\hline $\mathrm{TiH}_{2}$ & 26 & 1 & 0.82 & $4.2 \times 10^{-12}$ & 100.2 \\
\hline $\begin{array}{c}4 \mathrm{MgCO}_{3} \\
\cdot \mathrm{Mg}(\mathrm{OH})_{2}\end{array}$ & 11 & 10 & 1 & $2.3 \times 10^{-13}$ & 38.1 \\
$\cdot 5 \mathrm{H}_{2} \mathrm{O}$ & 11 & 1 & 0.083 & $1.5 \times 10^{-14}$ & 15.3 \\
\hline $\mathrm{MgCO}_{3}$ & 3.5 & 2 & 0.029 & $1.4 \times 10^{-16}$ & 3.3 \\
\hline $\left.\mathrm{CaMg}^{2} \mathrm{CO}_{3}\right)_{2}$ & & & & & \\
\hline
\end{tabular}

The $4 \mathrm{MgCO}_{3} \cdot \mathrm{Mg}(\mathrm{OH})_{2} \cdot 5 \mathrm{H}_{2} \mathrm{O}$ foam grows as a torn cell structure because the oxidizing gases $\mathrm{H}_{2} \mathrm{O}$ and $\mathrm{CO}_{2}$ are released by $4 \mathrm{MgCO}_{3} \cdot \mathrm{Mg}(\mathrm{OH})_{2} \cdot 5 \mathrm{H}_{2} \mathrm{O}$ decomposition. This stabilizes the cell wall by oxidization, which prevents the cell from becoming connected and spherical, and leads to the coarse-torn cell structure. To support this, it has been reported that the carbonate foam oxidizes and stabilizes the cell wall. ${ }^{3)}$

$\mathrm{MgCO}_{3}$ and $\mathrm{CaMg}\left(\mathrm{CO}_{3}\right)_{2}$ have higher decomposition temperatures than $\mathrm{TiH}_{2}$ and $4 \mathrm{MgCO}_{3} \cdot \mathrm{Mg}(\mathrm{OH})_{2} \cdot 5 \mathrm{H}_{2} \mathrm{O}$, and $<1 \%$ of the decomposition gas has been released when $\mathrm{AlSiCu}$ starts melting. Most of the decomposition gas is released while $\mathrm{AlSiCu}$ melting is well under way, which reduces the flow stress of $\mathrm{AlSiCu}$. These cells do not have torn fibrous aluminum powder boundaries, and their structures could be flat or spherical. Even after expansion, the shape and homogeneity of the cell structure are maintained because of the stability of the cell wall. 
To confirm the effect of the released gas volume on the cell structure, the volume and radius of gas released from a particle at $843 \mathrm{~K}$ are given in Table 3 . The gas volume of one mole $\left(0.0224 \mathrm{~m}^{3}\right)$ was used as the standard condition. $4 \mathrm{MgCO}_{3} \cdot \mathrm{Mg}(\mathrm{OH})_{2} \cdot 5 \mathrm{H}_{2} \mathrm{O}$ has a large volume because most of the gas has already been released at $843 \mathrm{~K} . \mathrm{MgCO}_{3}$ and $\mathrm{CaMg}\left(\mathrm{CO}_{3}\right)_{2}$ have small volumes because most of the gas has not been released at $843 \mathrm{~K}$.

The gas released from $\mathrm{CaMg}\left(\mathrm{CO}_{3}\right)_{2}$ has a smaller radius than that released from $\mathrm{MgCO}_{3}$, and the cell structure also depends on the particle size. The smaller radius of the oxidizing gas released from $\mathrm{CaMg}\left(\mathrm{CO}_{3}\right)_{2}$ presumably contributes to the fine and spherical cell structure observed for the $\mathrm{CaMg}\left(\mathrm{CO}_{3}\right)_{2}$ foam.

\section{Conclusion}

A carbonate foaming agent that begins decomposing after the matrix has melted is required for the formation of metal foams with a fine and homogenous cell structure by the PM route. The $\mathrm{TiH}_{2}$ foam formed under similar conditions showed markedly different characteristics, and had a coarse and rounded cell structure. $\mathrm{MgCO}_{3}$ and $\mathrm{ML}-\mathrm{CaMg}\left(\mathrm{CO}_{3}\right)_{2}$ were selected as the suitable foaming agents of $\mathrm{AlSiCu}$. The $\mathrm{CaMg}\left(\mathrm{CO}_{3}\right)_{2}$ foam had a specific gravity of 1.19 and a homogeneous, fine and spherical cell structure.

\section{REFERENCES}

1) T. Miyoshi, M. Itoh, S. Akiyama and A. Kitahara: Porous and Cellular Materials for Structural Applications, MRS Symposium Proceeding, San Francisco, USA, Ed. by D. S. Schwartz, (1998) pp. 133-137.

2) J. Baumeister: German Patent 4018360 (1990).

3) T. Nakamura, S. V. Gnyloskurenko, K. Sakamoto, A. V. Byakova and R. Ishikawa: Mater. Trans. 43 (2002) 1191-1196.

4) J. W. Smith and D. R. Johnson: Thermochim. Acta 8 (1974) 45-56.

5) H. Iimi, K. Kameyama, Y. Suzuki, Y. Naganawa, E. Kato and H. Nomura: Denso Technical Rev. 6 (2001) 100-106. 